immunological parameters in patients with atopy allow to suggest the significant role of allergic and neuropeptide inflammation of the esophageal mucosa in children with allergic diseases.

\section{GP179 THE INCIDENCE OF INFLIXIMAB INFUSIONS IN PAEDIATRIC IBD PATIENTS IN A TERTIARY PAEDIATRIC GASTROENTEROLOGY CENTRE}

Beth Gordon*, Ciara Langa, Karen O'Driscoll, Siobhan Kiernan, Billy Bourke, Annemarie Broderick, Seamus Hussey. Gastroenterology Department, Our Lady's Children Hospital Crulim, Dublin, Ireland

\subsection{6/archdischild-2019-epa.240}

Background Infliximab is a chimeric monoclonal antibody that targets Tumour Necrosis Factor-a in inflammatory bowel disease (IBD). Our Lady's Children Hospital Crumlin is the sole tertiary paediatric gastroenterology service in Ireland caring for the IBD paediatric population.

Our practice has been using the Infliximab originator, Remicade, for treatment. In our centre, for each patient commencing Infliximab treatment, we follow a specific protocol with regards to infusion rates, pre-medication and observation post infusion.

Objectives Our primary objective was to assess the incidence of adverse infusion reactions to Infliximab.

Methods We performed a retrospective analysis of patient charts who were on Infliximab infusions prior to the introduction of the biosimilar Infliximab infusion in October 2018 in our centre.

We reviewed a cohort of 100 patients who received Infliximab infusions during the time period $1^{\text {st }}$ January 2016 to $30^{\text {th }}$ September 2018. We assessed for any ADR ranging from mild requiring medical review to severe, requiring rescue adrenaline for anaphylaxis, as documented in patient notes and medication charts.

In view of practice changes to infusion rate times and evidence on exclusion of pre-medications, we aimed to investigate our current infusion adverse drug reactions (ADR) to compare going forward with the biosimilar switch.

Results In our cohort, $42 \%$ patients were female and $58 \%$ male. The majority 74\% ( $\mathrm{n}=74)$ of patients were diagnosed with Crohn's disease, whilst 25\% $(n=25)$ had a diagnosis of Ulcerative Colitis and $1 \%(\mathrm{n}=1)$ with IBD-undetermined. The average age of diagnosis was 11.8 years (Range $=3.4$ 16.4). $10 \%(\mathrm{n}=10)$ of patients were commenced on Infliximab at diagnosis as inpatients with the remaining $90 \%$ attending as outpatients to the day ward.

The overall incidence of Infliximab infusion reactions was $4 \%(n=4)$. Significant severe non-anaphylactic infusion reaction, occurred in one patient only $(1 \%)$. Of note, the patient did not receive adrenaline and was treated with IV hydrocortisone and IV chlorphenamine as per the protocol. 2\% $(n=2)$ were classed as moderate reactions with rash and facial flushing, both given IV hydrocortisone. Mild reaction occurred in $1 \%(n=1)$ with an episode of central chest pain that warranted medical review and the infusion re-started with a slower rate.

Conclusions Infliximab Infusion reactions are rare and found in a small quantity among paediatric IBD patients. Going forward with the biosimilar switch in our centre we can compare this data to assess its safety profile.

\section{GP180 LEVEL OF VITAMINS D, PARATHORMONE, BONE TISSUE METABOLITES IN CHILDREN WITH COELIAC DISEASE AND BONE FRACTURES}

'Leonid Klimov, 'Marina Stoyan, 'Lyudmila Abramskaya, 2Irina Zakharova*, ${ }^{1}$ Victoria Kuryaninova, 'Dmitriy Bobryshev, 'Vyacheslav Kashnikov, 'Svetlana Kashnikova. ${ }^{1}$ Stavropol State Medical University, Stavropol, Russian Federation; ${ }^{2}$ Russian Medical Continuing Postgraduate Academy, Moscow, Russian Federation

\subsection{6/archdischild-2019-epa.241}

Objectives Study of vitamin D (VD) reserves and the level of markers of bone remodeling in children and adolescents with celiac disease (CD) depending on the presence or absence of fractures in history.

Methods 149 children with CD aged 1-17 y $(8.8 \pm 0.7 \mathrm{y})$, among which $65(43.6 \%)$ boys, $84(56.4 \%)$ girls. The diagnosis was established in accordance with the ESPGHAN criteria (1990,2012). Patients were divided into 2 groups. The 1 group $20(13.4 \%)$ children who had a history of fractures, the 2 group - 129(86.6\%) children who had no fractures in the anamnesis. All patients were tested for serum calcidiol, osteocalcin(CSC), parathyroid hormone(PTH), C-terminal telopeptides(C-TTR).

Results The overall incidence of fractures in children with CD $13.4 \%$, while in boys they occur 2.4 times more often $20.0 \%$ versus $8.3 \%$ in $\operatorname{girls}(\mathrm{p}<0.05)$. The average age of diagnosis of $\mathrm{CD}$ in patients without fractures $4.3 \pm 0.3 \mathrm{y}$, in children with fractures $6.1 \pm 1.0 \mathrm{y}(\mathrm{p}<0.05)$. During the first year of adherence to GFD 3(23.1\%) out of 13 fractures occurred. The average age of the fractures that occurred before the diagnosis was $5.9 \pm 0.9 \mathrm{y}$; on the background of GFD $8.8 \pm 0.9 \mathrm{y}$. Fractures of the upper and lower extremities were diagnosed in children in $15(75.0 \%)$ and $5(25.0 \%)$ cases. In patients with fractures calcidiol $12.4 \pm 2.0 \mathrm{ng} / \mathrm{ml}$, 1.9 times lower than in patients in the control group $23.0 \pm 1.2 \mathrm{ng} / \mathrm{ml}(\mathrm{p}<0.01)$. VD deficiency in children with fractures was in $18(90.0 \%)$ children, of which in $9(45.0 \%)$ children it was severe $(>10 \mathrm{ng} / \mathrm{ml})$. Deficiency VD $1(5.0 \%)$ patient, optimal level only $1(5.0 \%)$ patient. In the comparison group, VD deficiency in $70(54.3 \%)$ children, of them severe $33(26.3 \%)$, VD deficiency 21 (16.3\%) cases, and the optimal level - in $38(29.4 \%)$ patients. The level of PTH in children with fractures was $47.0 \pm 9.7 \mathrm{pg} / \mathrm{ml}$, which is 1.6 times higher than in the comparison group - $30.2 \pm$ $2.0 \mathrm{pg} / \mathrm{ml}(\mathrm{p}<0.05)$. The level of CSC in children with fractures was lower than in the comparison group - 27.0 \pm 4.4 $\mathrm{ng} / \mathrm{ml}$ and $53.9 \pm 2.6 \mathrm{ng} / \mathrm{ml}(\mathrm{p}<0.001)$, while C-TTR values were higher $-132.1 \pm 20.1 \mathrm{pg} / \mathrm{ml}$ and $96.8 \pm 6.9 \mathrm{pg} / \mathrm{ml}$, respectively $(\mathrm{p}<0.05)$.

Conclusion CD patients at any age are at high risk for osteopenia and osteoporosis. A study of calcidiol indicates a low level concentration in children and adolescents with CD, while children with fractures have even lower rates.

\section{GP181 COMPARING DIAGNOSTIC TESTS IN CHILDREN WITH COW'S MILK PROTEIN ALLERGY}

${ }^{1}$ Dominika Lendvai-Emmert, ${ }^{2}$ Vanessza Emmert* ${ }^{*}{ }^{1}$ Katalin Fusz, ${ }^{1}$ Viktória Prémusz, ${ }^{1}$ Viktória Németh, ${ }^{2}$ Gergely Tóth. ${ }^{1}$ University of Pécs, Pécs, Hungary; ${ }^{2}$ Erzsébet Teaching Hospital and Rehabilitation Institute, Sopron, Hungary

10.1136/archdischild-2019-epa.242

Introduction Food allergies are very common in the pediatric population; the most common among them is cow's milk 